\title{
Assessment of environmental water requirement for rivers of the Miankaleh wetland drainage basin
}

\author{
V. Gholami ${ }^{1} \cdot$ A. Khalili ${ }^{2} \cdot$ H. Sahour ${ }^{3} \cdot$ M. R. Khaleghi ${ }^{4} \cdot$ E. Nikzad Tehrani $^{5}$
}

Received: 21 June 2020 / Accepted: 19 October 2020 / Published online: 2 November 2020

(c) The Author(s) 2020

\begin{abstract}
The Miankaleh wetland, one of the richest ecosystems in the north of Iran, has experienced an unprecedented environmental degradation caused by overexploitation of the water resources and climatic changes in recent years. This research aims to estimate the environmental water requirement (EWR) for the rivers that drain into the wetland. For this purpose, comprehensive data were collected through physiographic, climatic, hydrologic, ecologic, and field studies of the wetland and its drainage basin. To estimate the EWR, we applied several methods including the Tenant, the Eco-deficit, the flow duration curve, the Wetted-Perimeter method, and the physical habitat simulation model (PHABSIM) and the results were evaluated based on the natural discharge of the rivers before retrogression of the Miankaleh wetland. Further, the results showed that the consideration should be given to the Wetted-Perimeter and the PHABSIM Model for estimation of the EWR for the rivers of the Miankaleh wetland given the seasonality of the rivers and hydroclimatic condition of the study area. The mean annual EWR of the rivers was estimated between 0.12 and $2.03 \mathrm{~m}^{3} / \mathrm{s}$, which is close to the values of the bank full flows. The current discharge of the rivers are less than the estimated EWR, showing the discharge rates do not meet the water requirement for aquatic species of the Miankaleh wetland
\end{abstract}

Keywords Wetland restoration - Environmental water requirement $\cdot$ The wetted-perimeter method $\cdot$ PHABSIM model

\section{Introduction}

Wetland, as a unique hydrologic feature of a landscape (US EPA 2008), is one of the most vulnerable aquatic ecosystems due to their seasonal fluctuations in water depth (Krasnostein and Oldham 2004; Kate et al. 2020). These ecosystems,

V. Gholami

Gholami.vahid@guilan.ac.ir

1 Department of Range and Watershed Management and Department of Water Engineering and Environment, Faculty of Natural Resources, University of Guilan, Sowmeh Sara, Guilan, Iran

2 Department of Water Engineering, Faculty of Agriculture, University of Birjand, Birjand, Iran

3 Marine Science Institute, The University of Texas at Austin, Port Aransas, TX 78373, USA

4 Department of Range and Watershed Management, Torbat-e-Jam Branch, Islamic Azad University, Torbat-e-Jam, Iran

5 Department of Range and Watershed Management, Faculty of Natural Resources, University of Mazandaran, Sari, Iran which are managed as part of the regulated water systems, often require external water supplies to support their desired ecological role in the hydrosphere (Jia and Luo 2009). Wetlands act as a passing zone between aquatic and terrestrial ecosystems and therefore contain characteristics of both environments (US EPA 2008). Three hydrologic descriptors are used for characterizing the hydrologic behavior of the wetlands: the general wetland water level related to the soil surface, the temporal variation of water depths and the residence, or travel time (US EPA 2008). There is also another descriptor called hydropattern, which, according to King et al. (2004), describes the variation of water depths over time and space. All of the descriptors mentioned above are influenced and controlled by hydrologic inputs and outputs. Water discharge is the key driver of wetlands ecosystem processes and exerts significant control on their environments (Adhikari et al. 2019). Regarding that, the determination of the flow required for hydrological and environmental purposes is essential for environmental flow assessment.

The extent that an aquatic ecosystem can withstand the environmental and hydrological stresses on its own is called the aquatic ecosystem tolerance threshold or ecological 
threshold. The ecological threshold is the point at which a relatively small change or disturbance in external conditions causes a rapid change in an ecosystem. When an ecological threshold is passed, the ecosystem may no longer be able to return to its steady-state through its inherent resilience (Groffman et al. 2006). For this reason, all aquatic ecosystems need a certain amount of water to maintain their standard hydrological and environmental requirements (Akhtar et al. 2020), which is called the environmental water requirement (EWR). According to Kinhill (1988), there are three groups of methodologies for determining environmental flow requirements: empirical methods, transect or passage, and available habitat. Water budget components for characterizing the behavior of wetland systems are precipitation, evapotranspiration, groundwater recharge and discharge, and the interaction between surface water and marine systems (Brinson 1993). Nowadays, population growth and overuse of aquatic resources in many parts of the world have caused irreparable impacts on the function of wetlands ecosystems (Cui et al. 2012; Anthonj et al. 2018; Pattison-Williams et al. 2018). Thus, the issue of the eco-environmental water requirement has become a hotspot of eco-environmental studies (Cao et al. 2020). Moreover, alteration of the water regime as a driving factor in wetland ecosystems results in severe degradation of wetlands (Xu et al. 2017). Hence, evaluation of the EWR is essential for wetland protection, recovery, and restoration (Yang et al. 2012). In this regard, providing the required water for wetlands can restore their ecological conditions and can play a significant role in improving their environmental performances.

Construction of dams and exploitation of water resources has led many countries to provide methods for assessing the EWR to preserve their aquatic ecosystems (Tharme 2003; Malekmohammadi and Jahanishakib 2017). In Australia, Arthington and Zalucki (2002) applied the holistic method to determine the EWR of the Barker-Barambah River. The holistic method is approved by the Ramsar International Convention to determine the EWR of wetlands (Ramsar handbooks 2010). The holistic method is one of the most effective methods because it determines the natural hydrological regime on an appropriate scale with considering various factors such as climate, geomorphology, vegetation cover and animals' water requirements, and human interventions (Arthington 1998; Pusey 1998).

In another research in Australia, Coletti et al. (2017) applied an eco-hydrological model on a semi-arid saltaffected wetland exposed to hydrological manipulation to develop its salinity and vegetation dynamics. Yang (2011) applied a hybrid method to determine the EWR of the Yellow River wetlands. The purpose of their study was to determine the optimal monthly water release into the Yellow River Delta wetlands to improve the livelihoods of their riparian inhabitants. Yang et al. (2012) applied a combined method to investigate the relationship between water quantity and water quality in Baiyangdian wetlands and determined its ecological water requirement. Sarhadi and Soltani (2013) applied hydrological approaches for measuring a required base flow for wetlands. They concluded that the hydrological methods could dependably estimate the EWR for wetlands in arid and semi-arid regions. Sajedipour et al. (2017) estimated the EWR using an ecological approach and concluded that the allocation of EWR is the most effective manner to protect wetlands. In another study in western China, Ye et al. (2017) applied an ecological method based on water depth frequency analysis to evaluate the impacts of water depth fluctuations on the ecosystem of the Bosten Lake wetlands. According to their results, in determining and allocating the EWR, consideration should be first given to, ecological characteristics of the ecosystem, and then evaluation of the water quality.

This research describes the application and evaluation of various methods to estimate EWR for the rivers that drain into the Miankaleh wetland, which is located in the north of Iran. The provision of the EWR will ensure the life of wetland and native species. Miankaleh wetland is one of the richest ecological havens in Asia and is home to many native Caspian birds and reptile species. This wetland is also an internationally recognized refuge for migratory birds. The goal of this research is to estimate the EWR of the rivers that drain into the Miankaleh wetland drainage basin. The EWR of these rivers guarantees the life of the wetland's aquatic species. Further, to perform a comparative analysis to identify the most suitable method for estimation EWR in the study region.

\section{Methods and materials}

\section{Study area}

The study area is the Miankaleh Wetland $\left(52^{\circ} 25^{\prime}-54^{\circ} 02^{\prime} \mathrm{E}\right.$ longitude and $36^{\circ} 46^{\prime}-36^{\circ} 53^{\prime} \mathrm{N}$ latitude) located in the south-east extremity of the Caspian Sea in the north of Iran (Fig. 1). The Miankaleh peninsula, with an area of 24,000 ha, is a relatively flat sand dune that separates Gorgan Bay from the Caspian Sea. The mean annual precipitation is about $600 \mathrm{~mm}$, and the mean annual temperature of the region is $17{ }^{\circ} \mathrm{C}$ with a climate ranging from warm semi-humid to temperate (Ghahroudi Tali et al. 2012). The maximum, minimum, and mean elevations of the wetland are $-27,-20$, and $-24 \mathrm{~m}$, respectively. Miankaleh peninsula is one of the most important sanctuaries of wildlife and water ecosystems of Iran in which human activities and climatic changes of the past decades (Tehrani et al. 2018) have significantly affected the structure and function of this wetland. The Miankaleh region is of high importance for the 


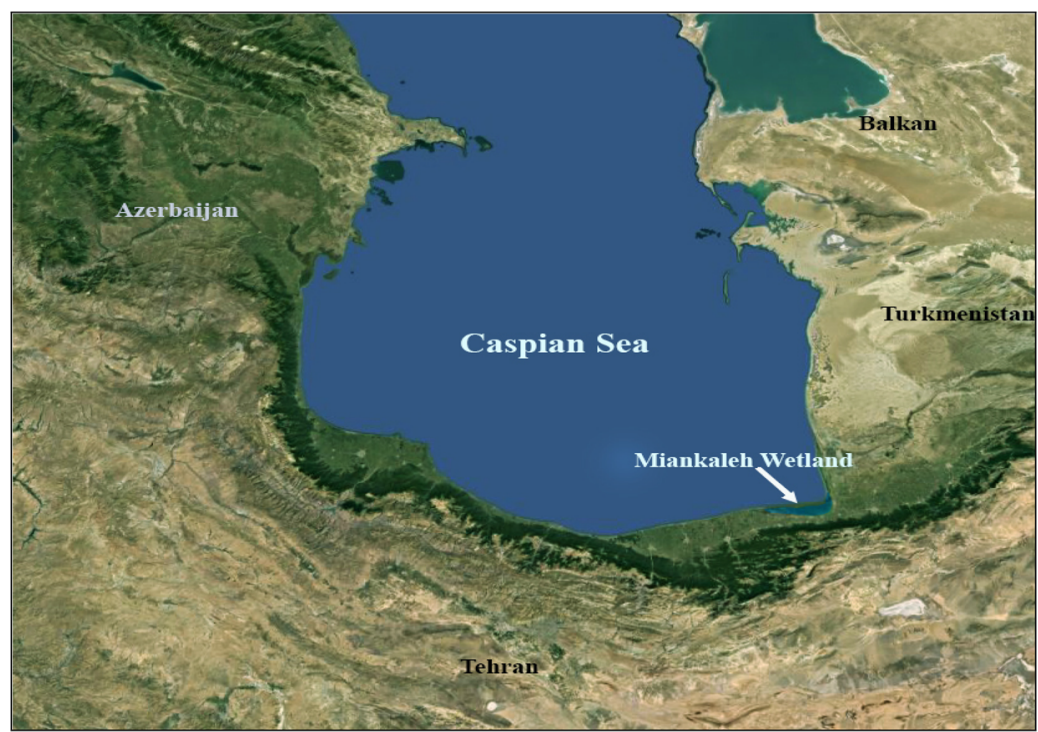

(a)

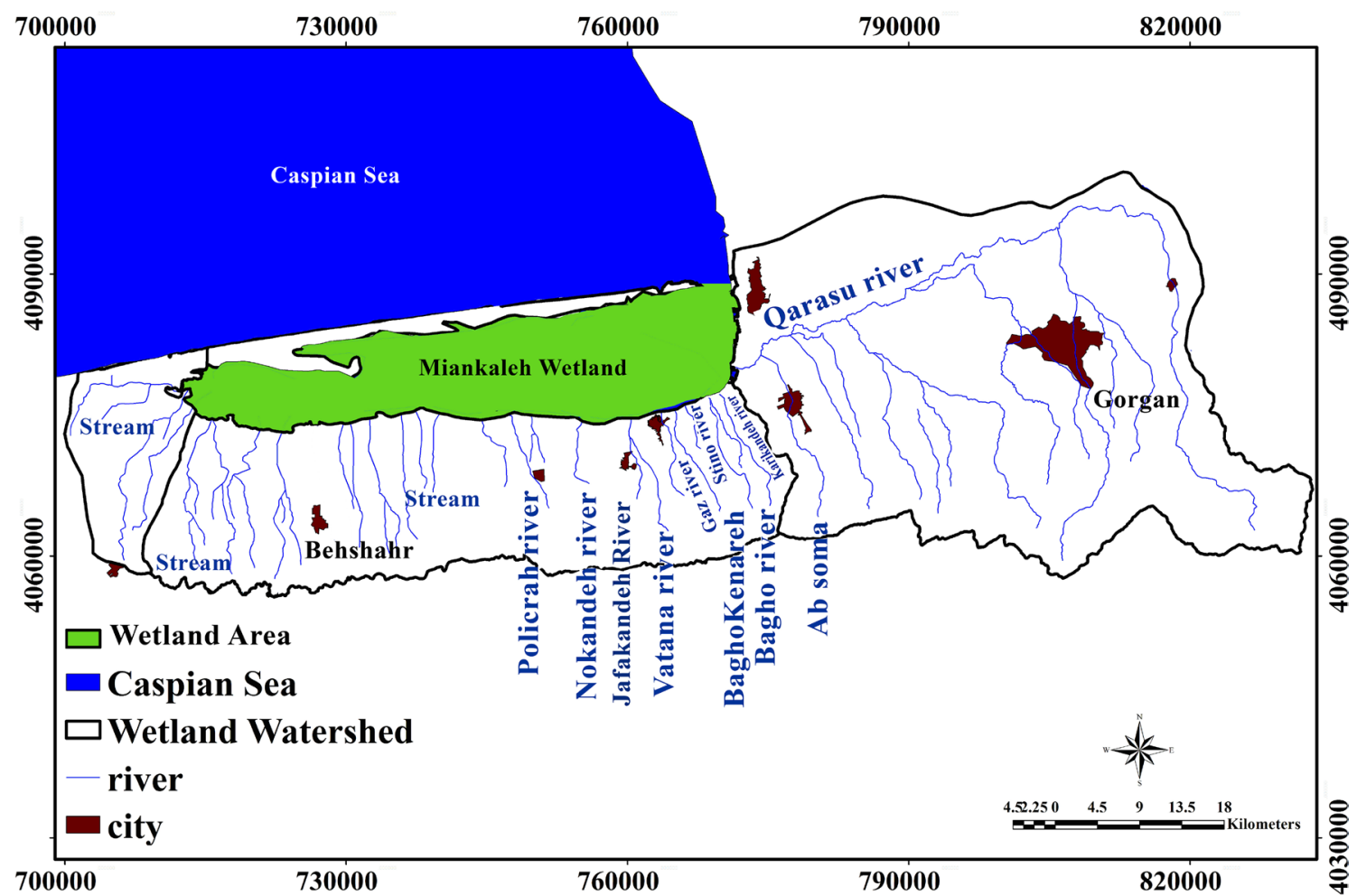

(b)

Fig.1 a Location of the Miankaleh wetland, $\mathbf{b}$ the rivers of the wetland's watershed

wintering of many rare species of migratory birds and the breeding of native bird species during summer. Permanent rivers that discharge into the wetland are Qarasu, Vatana, Bagho, and Gaz rivers. With its natural characteristics, this wetland is one of the most valuable vegetation and animal habitats in Iran. The wetland also plays a substantial hydrological and ecological role in the functioning of the coastal systems. The Miankaleh wetland, as one of the world's valuable ecosystems with a rich diversity of fauna and flora, has been designated as a Ramsar site since 1975. The region has a high cultural and educational position, and because of its cultural heritage and historical and aesthetic structures, it has been recognized by UNESCO as a biosphere reserve (Seifi and Janbaz Ghobadi 2017). 


\section{Estimation of the EWR for the Miankaleh wetland}

The main objective in estimating the EWR of the Miankaleh is to determine the minimum water, which guarantees the continuation of the wetland life. Considering the fact that the Miankaleh wetland is connected to the Caspian Sea, the water depth fluctuations of the Miankaleh are a function of the Caspian Sea water level. The focus of this study is on the water budget from adjacent rivers that drain into the Miankaleh wetland. The effects of river discharge into the wetland are mostly maintaining the salinity of the water and the soil moisture and vegetation cover around the wetland, rather than the wetland water depth. We applied and tested various methods, including hydrological methods, hydraulic rating methods, and the Physical Habitat Simulation (PHABSIM) model, to determine the environmental flow requirement of the wetland's rivers. Hydrological methods (Tennant, aquatics flow method, flow duration curve (FDC), Eco-deficit method, and range of variability approach method) undermine some critical components such as habitat conditions, and most of them are not suitable for the semi-arid and arid area. The hydraulic rating method determines the river flow requirements of fish habitats, based on time series analysis of the river flow data and identifying its critical cross sections. PHABSIM model simulates the relationship between river flow and the physical habitat of the target species. This simulation is performed using the physical structures of the rivers and river flow.

\section{Hydrological methods}

Methods based on hydrological indicators are the simplest and the most widely used methods for estimating environmental flow. In these approaches, it is assumed that plant and animal species are accustomed to the natural hydrological regime, and thus the rejuvenation of the ecosystem depends on the renewal of the historical regime. In this method, the environmental flow is determined either as a percentage of the average annual flow rate of the river, or a flow rate with a high frequency of exceedance on an annual, seasonal, or monthly time scale from the FDC. In the present study, hydrologic methods, including Tennant (1976), aquatics flow method, FDC, Eco-deficit method, and range of variability approach, were applied and evaluated.

Tenant or Montana is a simple method, according to which the percentage of river flow $(10,30$ and $60 \%)$ is considered as an ecological water requirement. In the aquatic flow method, it is assumed that the average flow in the driest month is sufficient for aquatic animals for a year unless the additional flow is needed to meet and reproduction needs. However, it should be noted that many rivers in Iran are seasonal, and there is no stream flows in the dry seasons; therefore, this method is not suitable for semi-arid areas.
Flow requirements for rivers can also be extracted from the FDC. The FDC is a cumulative probability distribution of observed flow in a stream over a long period. The FDC is represented by a plot that shows the percentage of time in which the streamflow equaled or exceeded a given value (Shaeri Karimi et al. 2012). Another method of hydrological determination of the ecological water requirement is the eco-deficit method. The concept of eco-deficit was first expressed by Homa et al. (2005) as a method for assessing the interactions between humans and EWR. First, the average annual FDC of the rivers is provided, which represents the flows in a normal (average) year, and is the average of several FDCs for the annual flow in a multi-year statistical period. In this step, the FDCs of the natural and current river flows of the rivers are presented. The area between the optional and natural river flow diagrams is called eco-deficit. This area represents the net volume of water that is not available to meet intra-flow needs in the current flow state due to water withdrawal. The range of variability approach is used to calculate the degree of hydrologic alteration for each indicator of hydrological alteration (IHA) and degree of habitat alteration. In this method, the variability of river habitats before and after dam construction is evaluated. Among the observed rivers in this study, only two small dams have been constructed over the Qarasu river, and there are no any other reservoirs or dams for other rivers.

\section{Hydraulic rating method}

The hydraulic rating method was initially developed to determine the river flow requirements of fish habitats in the USA, using time series data and by identifying the cross sections of riffles. In this method, the river hydraulics is modeled as a function of the flow, and the relationship between the hydraulic parameters such as the Wetted-Perimeter method, the depth, and flow velocity with the frequency of the target species is established. The target group is selected from endangered species so that in the absence of this flow, a significant reduction in the number of target species occurs. The Wetted-Perimeter is the most commonly used approach of the hydraulic rating method, and it assumes there is a direct relationship between the wetted perimeter in a riffle and fish habitat in the river. The target fishes (observed fish species) of Miankaleh wetland include Leuciscus aspius (Asp), Rutilus frisii (Kutum), Rutilus rutilus (Roach), Sander Lucioperca (Pike-perch), and Cyprinus carpio. In this method, first, the geometry of the riverbeds was simulated using a GIS extension (HEC-GeoRAS add-on) and topographic maps with a scale of 1:1000. The geometry then was entered into the HEC-RAS hydraulic model, and the hydrological model of the rivers was constructed using field studies by determining the discharge, cross sections, Manning roughness coefficients, and river flow regime. Then, 
by using the hydraulic model, the wetted perimeter and the discharge of the river sections were calculated, and using the methodology presented in Fig. 2, the environmental water flow at each section of the river was estimated. In Fig. 2, the breakage or the breaking point (Breaking point is a singular point of a plane curve with the property that two branches of the curve end in it in such a way that each has a (one-sided) tangent at the point different from the other) is the EWR. Finally, for each river, different sections or places were studied, and the average values of all sections were presented as the EWR for that river.

\section{The PHABSIM model}

The determining criteria in PHABSIM methods are the physical parameters (e.g., water depth, velocity, temperature) of the river and their suitability for the target species. The primary purpose of the PHABSIM is to establish the relationship between the physical and the ecological features of a river using the Habitat Suitability Index (CSI) and weighted usable area (WUA). The EWR in this method is determined based on the habitat sustainability curve (HSC) and the flow rate of the river or the risk of flow violation based on the Habitat Suitability Index (CSI) (Brooks 1997). In PHABSIM method, each section is divided into a number of cells in terms of section variability. Then, for every desired discharge, the suitability functions corresponding to the river parameters are compared to the existing state of each cell to define the cell suitability grade. Finally, the calculated grades for each parameter are combined to estimate the composite suitability index for each cell in the section. The final estimated index that is used to determine the EWR is called Weighted Usable Area (WUA), which is calculated as the sum of the area-weighted products of point CSI for the cross section or reach, where the area is that of the individual hydraulic cells. WUA is calculated as follows:

$\mathrm{WUA}=\left[\left(\sum A_{i} * \mathrm{CSI} i\right) / L\right] \times 1000$

where $A_{i}$ is the area of the cell $i$, CSI $i$ is the habitat suitability criteria of cell $i$, and $L$ is the length. The desirable conditions of the target fish habitats were investigated with respect to the flow rate, flow depth and flow velocity, or the riverbed conditions and nutrients of the rivers. Field studies evaluated the rivers' conditions. We applied the PHABSIM model, which is one of the most important and most widely used habitat simulation methods (Arthington 1998; Sajedipour et al. 2017). One of the shortcomings of this method is that the PHABSIM is limited to the habitat of fish species and does not consider other aquatic animal and plant

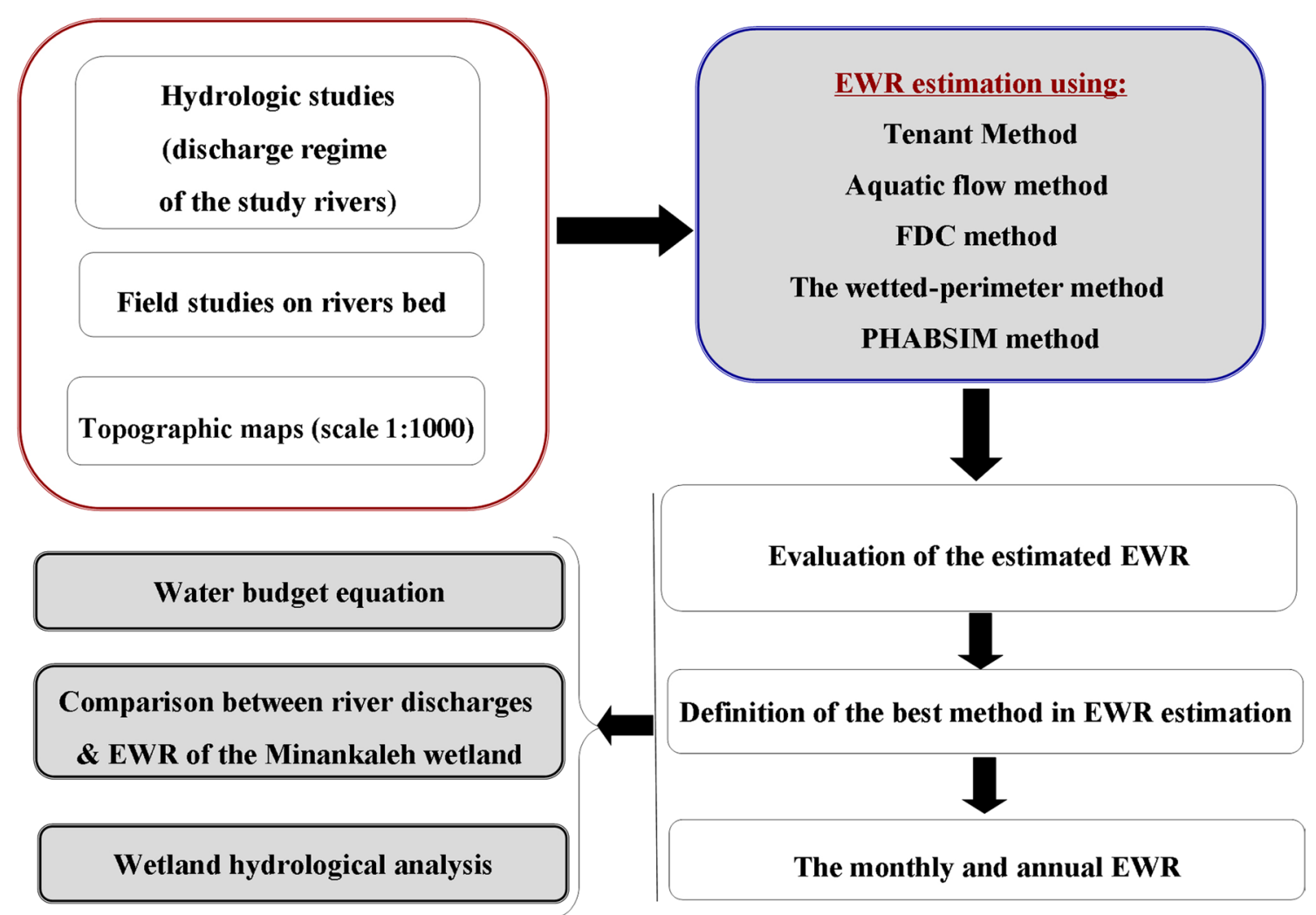

Fig. 2 The workflows of EWR estimation and the used methodology 
species. This model uses four hydraulic variables related to the quality of the fish's habitat, which was calculated by field measurements. The hydraulic variables included in the model are water depth, flow velocity, the substrate (the materials in the seafloor or riverbed, where aquatic organisms are attached to or are part of it), and coverage (safe areas in a river that preserves aquatic organisms from hunter). Micro-habitats are small physical areas in different parts of a river that are assumed to be directly related to the spatial distribution of the studied species. This model predicts how the change in flow rate would affect the water depth, water velocity, and various aspects of the riverbed and the target species. The habitat simulation method determines the optimal flow of habitats by modeling the effects of flow variation on aquatic habitats. In the process of modeling by habitat simulation method, the studied sites were selected by taking into consideration of the hydrological, morphological, geological features of the area and hydrological behavior of the rivers. However, we only selected the rivers with available time series data from hydrometric stations. Then, the initial hydrological model of the rivers was developed using the geographic information system (GIS) and the HEC-RAS hydraulic model. Additionally, field measurements, including the height of watermarks, velocity, and depth of water, the status of substrate materials, were conducted. Finally, the hydrological condition of the rivers and the rivers basements were simulated in the PHABSIM model, and according to the purpose of the hydrological demands of the target fish, the EWR of the rivers were estimated for different sections of each river.

\section{Evaluation of the methods}

In the present study, the criterion for evaluation of the methods for estimation of the EWR is the flow rate of the rivers in their natural state (before the retrogression process) and the bankfull flow of the rivers. Historical data were used to determine the discharge before the wetland retrogression in their natural state (without dams, reservoirs). When a river has a bankfull flow in cross sections, it means that the river is in good condition. Therefore, using the hydraulic model, the average bank full flow for all sections of each river was estimated. Finally, the estimated EWR was compared with the bankfull flow and the mean natural flow to evaluate the effectiveness of the methods. The workflows of EWR estimation and the used methodology are given in Fig. 3.

\section{Results}

We applied and evaluated several methods to determine the EWR for the rivers of the Miankaleh wetland, which have led to different values for each river. The Tennant method for the rivers of the Miankaleh wetland drainage basin did not provide acceptable results (Shaeri Karimi et al. 2012). Many of those rivers are dry in some seasons (spring and summer), and the rest are in their minimum flow status. The estimated values based on the Tennant method are less than $0.5 \mathrm{~m}^{3} / \mathrm{s}$. Also, for seasonal rivers, environmental flow requirements do not exceed $0.1 \mathrm{~m}^{3} / \mathrm{s}$.

The eco-deficit method also considers the average flow of the river in the warmest month of the year or monthly minimum flow. The EWR using this method was estimated at less than $0.45 \mathrm{~m}^{3} / \mathrm{s}$. Because a large number of observed rivers
Fig. 3 Estimation of EWR using the Wetted-Perimeter method

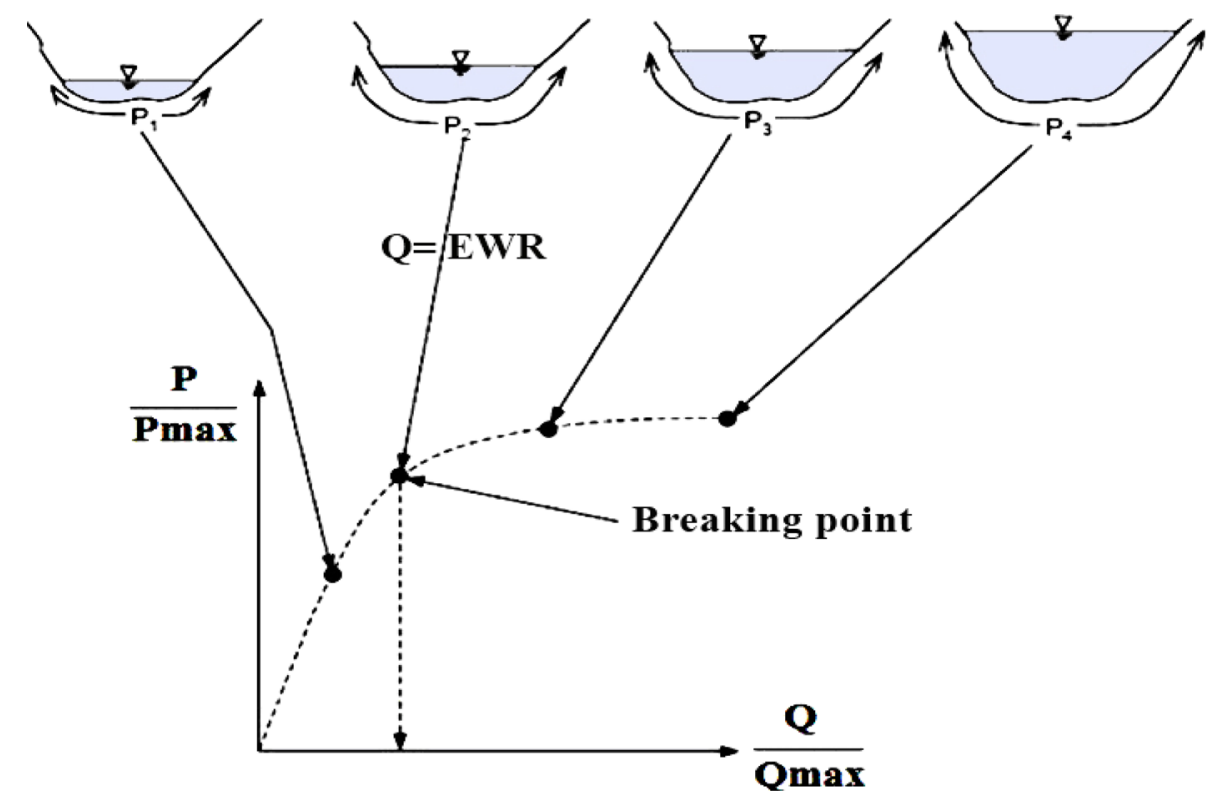


are the seasonal rivers, the Tennant and the eco-deficit are not suitable for them. Further, based on the FDC, the EWR of the rivers were estimated. The observed river discharge over a long period with an occurrence probability of $90 \%$ is estimated as EWR in the flow duration curve method. The estimated maximum EWR based on the flow duration curve for the Qarasu river was $0.47 \mathrm{~m}^{3} / \mathrm{s}$. The natural flow and the current river flow of the rivers were determined for modeling purposes. The criterion for determining the EWR was the natural discharge or discharge of the river without the effect of reservoirs or dams. Among the selected rivers, only the Qarasu river has two small dams built in the last decade. The natural and bank full flow values of the Qarasu river were determined and compared. Due to the small volume of reservoirs behind these dams and the limited extension of the dam's watershed, the difference between the natural flow and the current flow of the Qarasu river is insignificant. On the other hand, statistics and detailed information about the water withdrawal for this river are not available. Therefore, the eco-deficit method due to the absence of a dam or the absence of differences between natural and the current river flow (FDCs, natural, and Current River flows) did not provide acceptable results, and the estimated values were negligible. In the present conditions, the discharge of the rivers is significantly lower than that in the past. However, it should be noted that the criterion in the eco-deficit method is the difference between river flows in two modes of natural flow (without reservoirs and structures) and the current river flow (existence of reservoirs and structures), which is not the case in the rivers in this study.

In the Wetted-Perimeter method, a hydraulic model was run for the studied rivers. A sample of the simulated cross section for the Qarasu river and water depth is given in Fig. 4. Further, Fig. 5 shows an example of the wetted perimeter-flow curves. It should be noted that due to the necessity of providing the EWR of the Miankaleh wetland, the study sections in the Wetted-Perimeter method were determined within a few kilometers of the outlet of the watershed, which eventually end up to the Miankaleh wetland. Considering the cross-sectional maximum flow and past flows, the WettedPerimeter method showed relatively more acceptable results. The estimated EWR based on this method is ranging from 0.6 to 2.6 (based on the turning point in the Wetted-Perimeter method), which is close to the values for the natural flows and the bankfull flows.

PHABSIM model was used for simulating habitats and finally to estimate EWR. The habitat desirability curves for the target fish at younger stages, maturation, and spawning

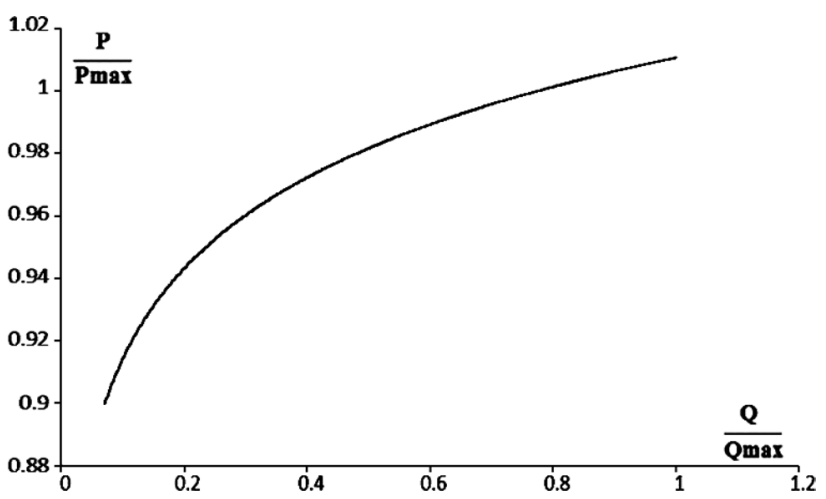

Fig. 5 Wetted perimeter discharge changes based on the WettedPerimeter method for one of the sections in the Qarasu river

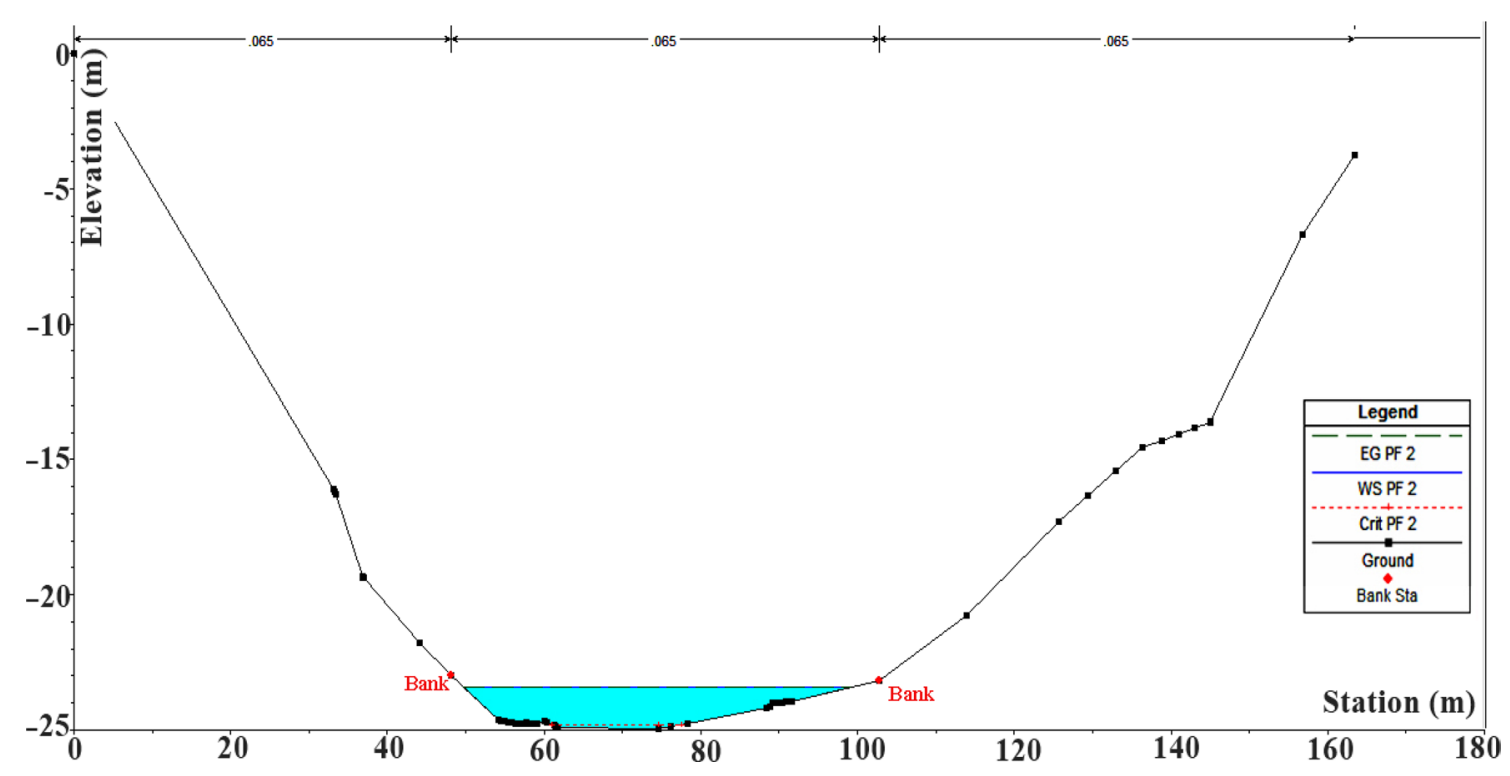

Fig. 4 A cross section of the Qarasu river and water depth (discharge $=1.5 \mathrm{~m}^{3} / \mathrm{s}$, Ground is river bed topography and WS PF2 is water depth) 
were presented for each of the observed rivers. Figure 6 shows an example of the desirability curve for Cyprinus carpio fish habitat for the stage of spawning in the Qarasu river.

The diagram of the discharge-weighted useable area for the Rutilus frisii Kutum in the Qarasu river is given in Fig. 7. Figures 8 and 9 show the diagram for the different lifetime of Rutilus rutilus caspicus specie in the Qarasu and the Jafakandeh rivers. In addition, the results of the simulation of the PHABSIM model for EWR of the Qarasu river (target fishes) for Rutilus frisii kutum and Rutilus rutilus caspicus are presented in Tables 1 and 2, respectively.

After estimating the environmental flow requirements of the rivers, it is necessary to examine the performance of the methods and determine the optimal method (s). For this purpose, the rivers' normal discharge and the bankfull flow were estimated and were compared with the estimated EWR for each river. Figure 10 shows the comparison of the minimum and average flows for the Qarasu river in its natural state with the estimated EWR using different methods. The values of the EWR of the eleven studied rivers are presented in Table 3. The methods without represented values in Table 3 indicate that the method does not provide an acceptable result or does not have the ability to determine the EWR in this particular climatic and hydrological conditions.
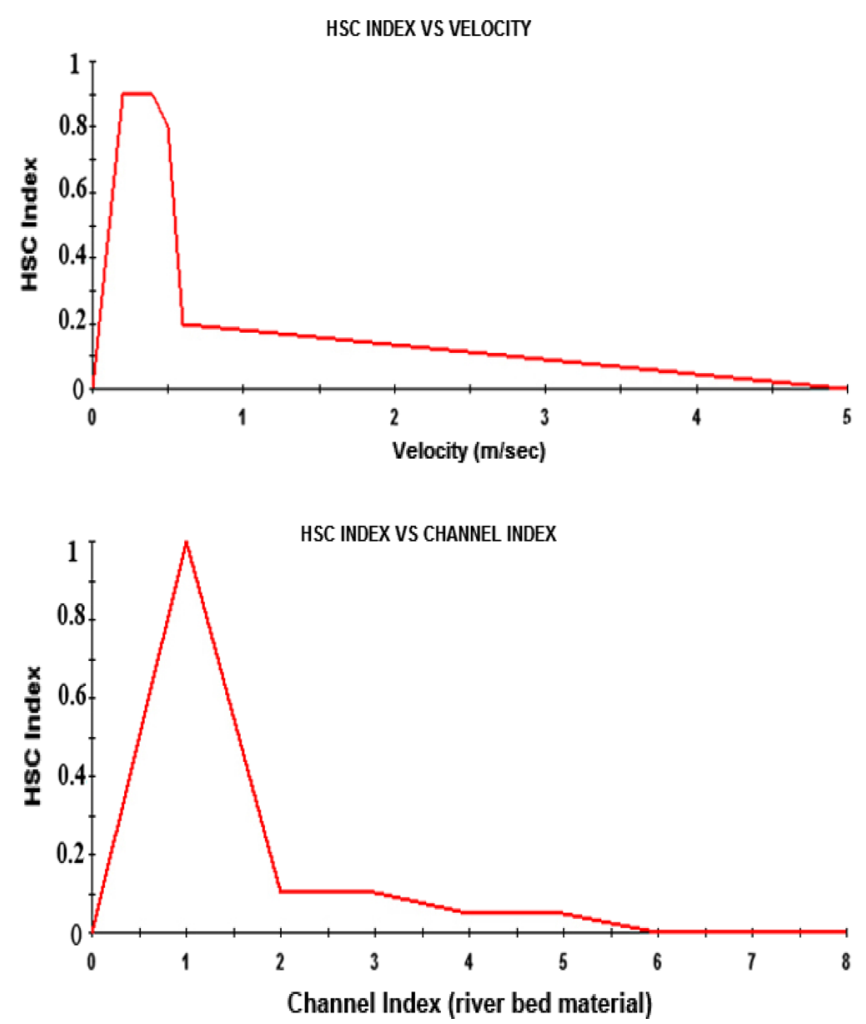

\section{Discussion}

Meteorological and hydrologic studies of the Miankaleh wetland drainage basin provide an overview of the status of the hydrological balance of this area. The average annual precipitation over the wetland is about $600 \mathrm{~mm}$, and the average annual evaporation is about $1000 \mathrm{~mm}$, which means that the evaporation rate is higher than precipitation (Tehrani et al. 2018). Considering the shallow depth of the wetland, the higher evaporation rate causes an increase in the salinity of the water and a severe threat to the water depth of the wetland (Sahour et al. 2020). Also, the discharge of rivers into the wetland is far less than their normal state, and most of them are dry during the spring and summer. Part of the water is being removed from the rivers during their minimum flow state for agricultural purposes. Therefore, the water balance of the wetland is negative, and the risk of drying is serious. Also, the salinity of groundwater due to saltwater leakage caused by groundwater depletion, made farmers shift toward using the surface water for agricultural purposes in this area. Therefore, we need to focus on providing the EWR of the rivers. In this research, different methods of determining the river's EWR showed a different level of capabilities.
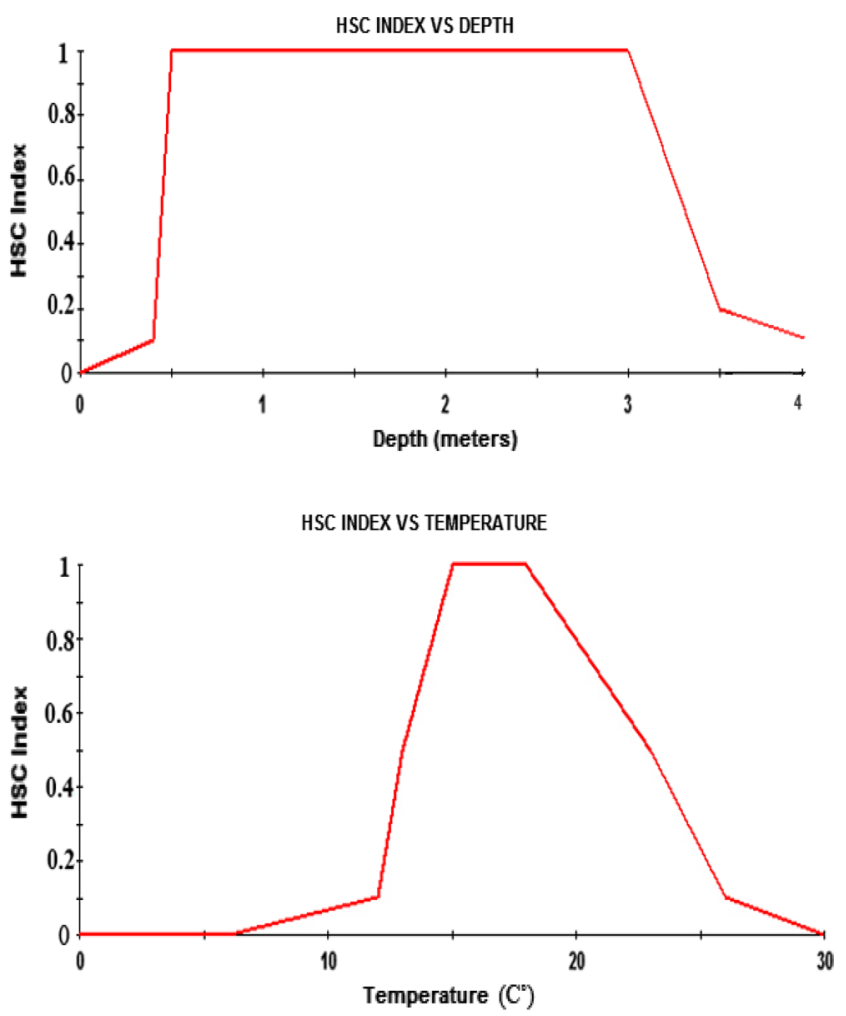

Fig. 6 Habitat Sustainability Curve for the Cyprinus carpio fish during spawning stage in the Qarasu river (channel index or the river bed materials) 


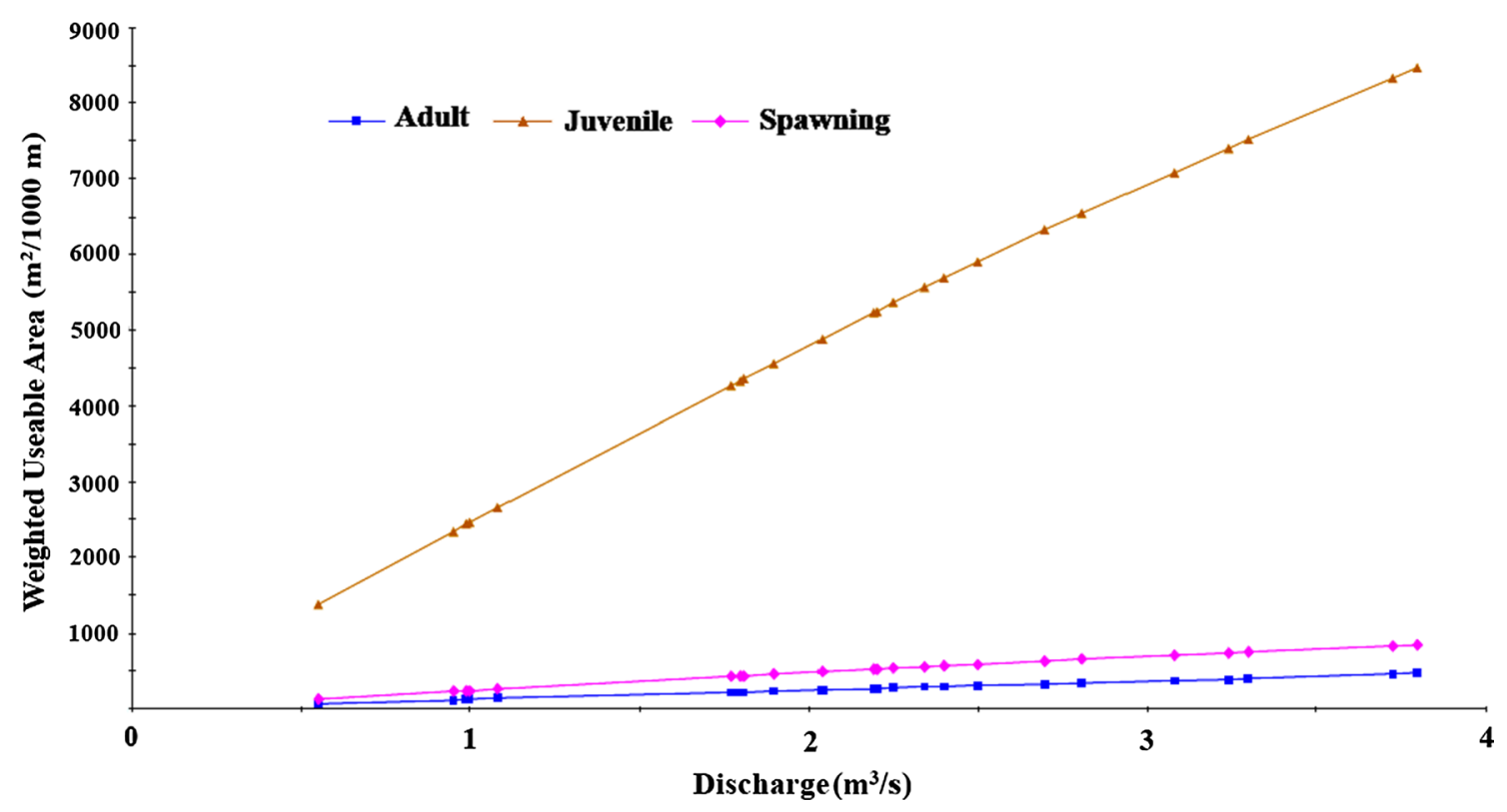

Fig.7 Discharge-weighted useable area for the Rutilus frisii kutum during three stages of juvenile fish, adult fish, and spawning in the Qarasu river

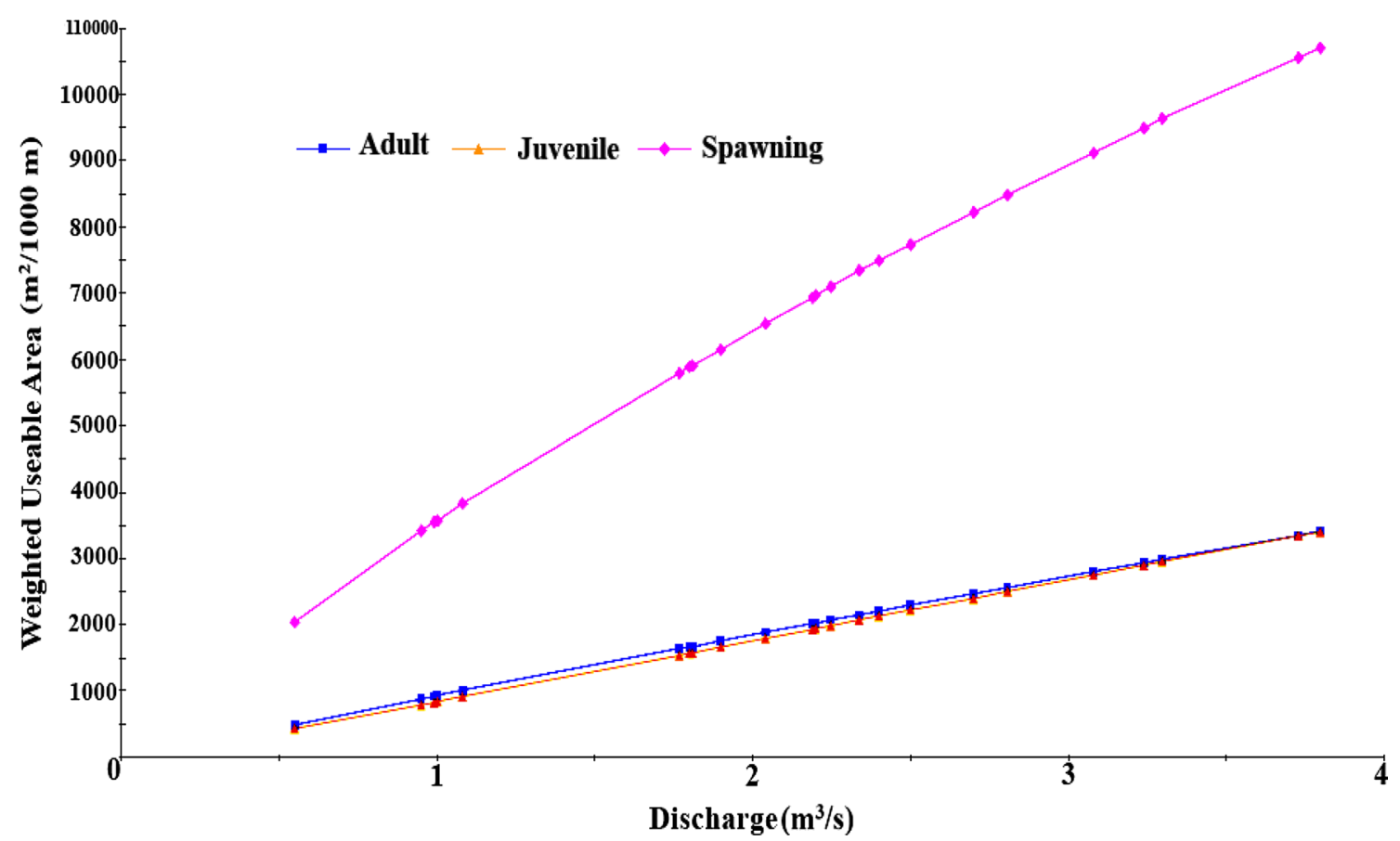

Fig. 8 Discharge-weighted useable area for Rutilus rutilus caspicus during three stages of juvenile fish, adult fish, and spawning in the Qarasu river

In the Tennant method, the river's environmental flow is expressed as a percentage of the average annual flow of the river at a particular site. In this method, the effects of human activities (water extraction, dam construction, runoff due to urbanization, etc.) should be eliminated for estimating the rivers' natural discharge. This method uses percentages of annual average flow to determine the quality of fish habitats. The estimated annual EWR values of the Tenant method have a range between 0 and $0.55 \mathrm{~m}^{3} / \mathrm{s}$ for the studied rivers. The Tennant method for seasonal rivers and especially in 


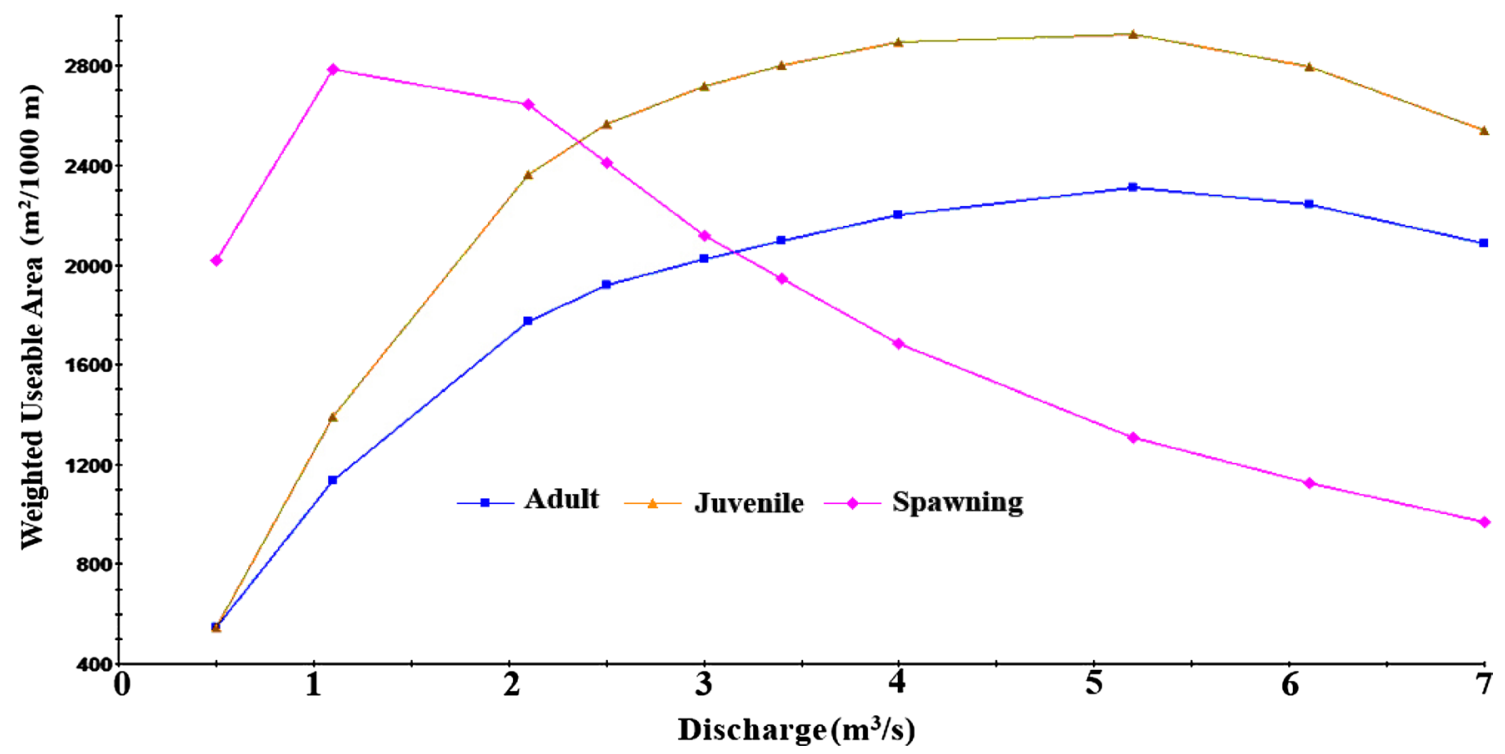

Fig. 9 Discharge-weighted useable area for Rutilus rutilus caspicus during three stages of juvenile fish, adult fish, and spawning in the Jafakandeh River

Table 1 EWR of the Qarasu river for the Rutilus frisii kutum during three stages of adult fish, juvenile fish, and spawning

\begin{tabular}{|c|c|c|c|c|c|c|c|}
\hline \multirow[t]{2}{*}{ Month } & \multirow{2}{*}{$\begin{array}{l}\text { Discharge } \\
\left(\mathrm{m}^{3} / \mathrm{s}\right)\end{array}$} & \multicolumn{2}{|l|}{ Adult fish } & \multicolumn{2}{|l|}{ Juvenile fish } & \multicolumn{2}{|l|}{ Spawning } \\
\hline & & $\begin{array}{l}\text { WUA } \\
\left(\mathrm{m}^{2} / 1000 \mathrm{~m}\right)\end{array}$ & $\operatorname{EWR}\left(\mathrm{m}^{3} / \mathrm{s}\right)$ & WUA $\left(\mathrm{m}^{2} / 1000 \mathrm{~m}\right)$ & $\operatorname{EWR}\left(\mathrm{m}^{3} / \mathrm{s}\right)$ & $\begin{array}{l}\text { WUA } \\
\left(\mathrm{m}^{2} / 1000 \mathrm{~m}\right)\end{array}$ & $\operatorname{EWR}\left(\mathrm{m}^{3} / \mathrm{s}\right)$ \\
\hline March & 3.73 & 462.10 & 3.23 & 8334.44 & 3.08 & 826.60 & 3.07 \\
\hline April & 2.81 & 338.89 & 2.38 & 6542.72 & 2.38 & 649.79 & 2.39 \\
\hline May & 1.90 & 229.31 & 1.62 & 4558.65 & 1.61 & 451.06 & 1.63 \\
\hline June & 0.95 & 114.38 & 0.82 & 2341.97 & 0.75 & 222.82 & 0.75 \\
\hline July & 0.55 & 63.29 & 0.47 & 1374.56 & 0.38 & 128.67 & 0.39 \\
\hline August & 0.45 & 51.62 & 0.39 & 1330.75 & 0.36 & 123.68 & 0.37 \\
\hline September & 0.99 & 119.31 & 0.86 & 2438.09 & 0.79 & 231.99 & 0.78 \\
\hline October & 1.08 & 130.34 & 0.93 & 2653.33 & 0.87 & 252.50 & 0.86 \\
\hline November & 1.77 & 213.83 & 1.51 & 4260.30 & 1.50 & 421.52 & 1.51 \\
\hline December & 2.19 & 263.87 & 1.86 & 5224.05 & 1.87 & 518.66 & 1.89 \\
\hline January & 2.25 & 273.27 & 1.92 & 5361.51 & 1.92 & 532.34 & 1.94 \\
\hline February & 3.08 & 370.05 & 2.59 & 7080.07 & 2.59 & 702.86 & 2.60 \\
\hline Annual & 1.18 & 218.59 & 1.54 & 4352.01 & 1.53 & 430.60 & 1.55 \\
\hline
\end{tabular}

the arid and semi-arid climate of Iran is not suitable because it will come up with a very small value for EWR (Shaeri Karimi et al. 2012). The benefits of the Tennant method are its simplicity and ease of use and its low cost. On the contrary, the disadvantage of this method is that the natural variations of water (monthly, daily, and annual fluctuations) are ignored, and only a minimum current flow is considered. In semi-arid regions, rivers may be dry seasonally, and thus the zero flow rate would be recommended as EWR, which makes this method unsuitable for these climatic conditions. Furthermore, in the Tennant or the Montana method, the relationship between the river discharge and the wetland ecosystem wellness is not adequately investigated.

The aquatic flow method of aquatic animals has also provided minimal values for EWR. Annual EWR based on the aquatic flow method was estimated between 0 and 0.45 $\mathrm{m}^{3} / \mathrm{s}$ for the studied rivers. Many rivers are dry in the warm seasons. Therefore, the estimation of EWR based on this method would also be zero, which means that this method is not suitable for the study area.

The flow-duration method has the same problem. This method estimated the EWR of the studied rivers between 0 
Table 2 EWR of the Qarasu river for the Rutilus rutilus caspisus in the stages of adult fish, juvenile fish, and spawning

\begin{tabular}{|c|c|c|c|c|c|c|c|}
\hline \multirow[t]{2}{*}{ Month } & \multirow{2}{*}{$\begin{array}{l}\text { Discharge } \\
\left(\mathrm{m}^{3} / \mathrm{s}\right)\end{array}$} & \multicolumn{2}{|l|}{ Adult fish } & \multicolumn{2}{|l|}{ Juvenile fish } & \multicolumn{2}{|l|}{ Spawning } \\
\hline & & WUA $\left(\mathrm{m}^{2} / 1000 \mathrm{~m}\right)$ & $\operatorname{EWR}\left(\mathrm{m}^{3} / \mathrm{s}\right)$ & WUA $\left(\mathrm{m}^{2} / 1000 \mathrm{~m}\right)$ & $\operatorname{EWR}\left(\mathrm{m}^{3} / \mathrm{s}\right)$ & WUA $\left(\mathrm{m}^{2} / 1000 \mathrm{~m}\right)$ & $\operatorname{EWR}\left(\mathrm{m}^{3} / \mathrm{s}\right)$ \\
\hline March & 3.73 & 3351.40 & 3.14 & 3339.73 & 3.18 & $10,559.14$ & 3.02 \\
\hline April & 2.81 & 2564.26 & 2.39 & 2498.57 & 2.40 & 8481.98 & 2.35 \\
\hline May & 1.90 & 1753.09 & 1.62 & 1659.49 & 1.63 & 6149.74 & 1.59 \\
\hline June & 0.95 & 882.97 & 0.79 & 792.61 & 0.82 & 3408.71 & 0.71 \\
\hline July & 0.55 & 492.58 & 0.42 & 431.88 & 0.49 & 2043.32 & 0.27 \\
\hline August & 0.45 & 446.60 & 0.38 & 333.50 & 0.40 & 2218.38 & 0.32 \\
\hline September & 0.99 & 921.26 & 0.83 & 828.44 & 0.85 & 3542.81 & 0.75 \\
\hline October & 1.08 & 1006.79 & 0.91 & 909.33 & 0.93 & 3837.23 & 0.85 \\
\hline November & 1.77 & 1634.97 & 1.50 & 1539.83 & 1.51 & 5792.73 & 1.48 \\
\hline December & 2.19 & 2017.15 & 1.87 & 1928.23 & 1.87 & 6937.54 & 1.85 \\
\hline January & 2.25 & 2071.81 & 1.92 & 1984.06 & 1.93 & 7098.90 & 1.90 \\
\hline February & 3.08 & 2798.05 & 2.61 & 2745.19 & 2.63 & 9119.83 & 2.55 \\
\hline Annual & 1.81 & 1671.29 & 1.54 & 1576.56 & 1.55 & 5902.87 & 1.51 \\
\hline
\end{tabular}

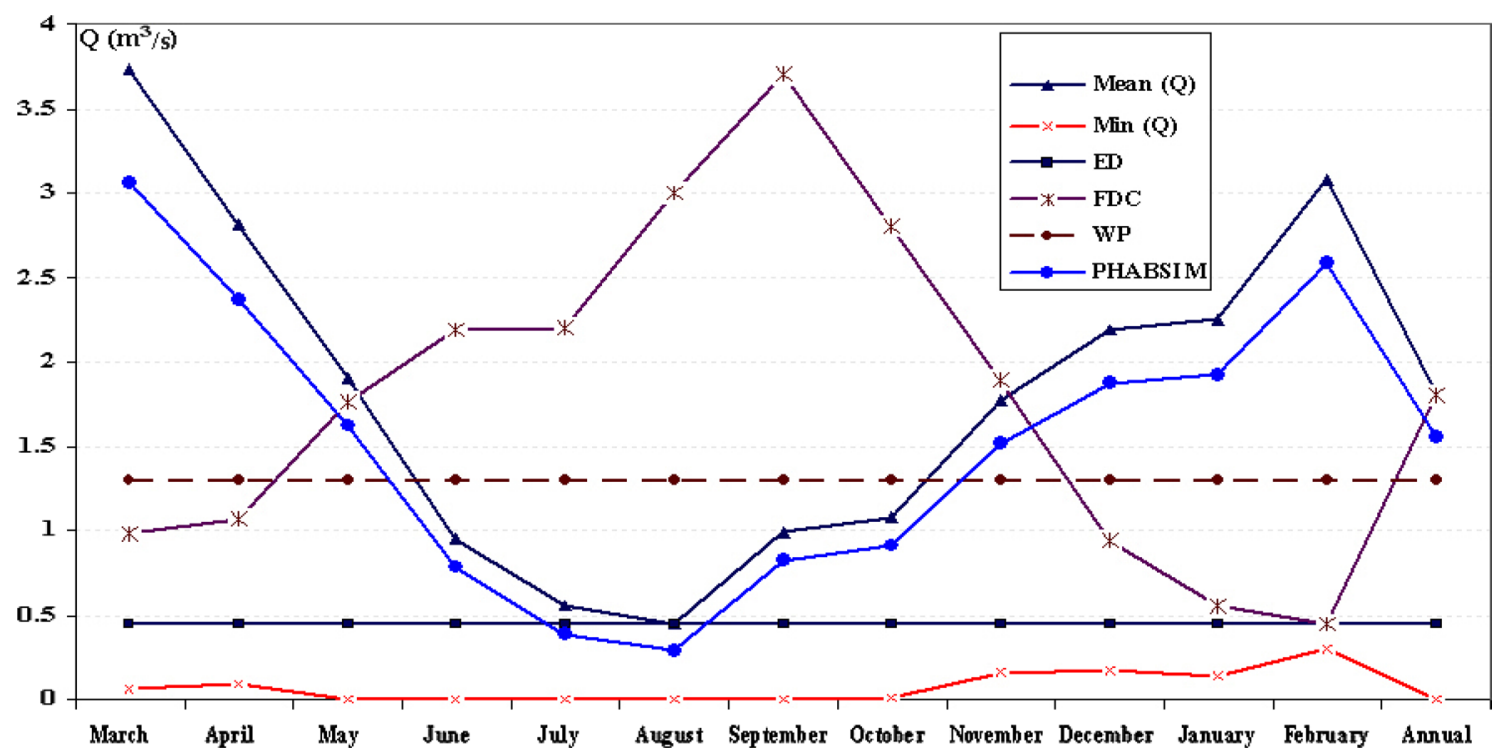

Fig. 10 The mean monthly and annual discharges of the Qarasu river and the estimated EWR using different methods. The Tenant method is not applicable to the rivers in this study Note: ED: Eco-deficit

and $0.47 \mathrm{~m}^{3} / \mathrm{s}$ for the studied rivers. Although this method provides more acceptable values compared to the first two methods, the results are not suitable for seasonal rivers. The Eco-deficit method seems to be a more capable method for the estimation of EWR in seasonal rivers. However, due to the lack of reservoirs on the rivers and the construction of only two small dams on the Qarasu river watershed, the difference in the volume of discharge caused by the construction of reservoirs is negligible, and therefore the estimated values for this method also are not acceptable.

Among the hydraulic methods, the Wetted-Perimeter method was used. The most important advantage of this method; FDC FDC method, WP the Wetted-Perimeter method (EWR changes from 0.22 to 35 in the different sections and the mean is 1.3); PHABSIM model

method is its simplicity and ease of use. This method estimated the EWR of the studied rivers between 0.62 and 2.03 $\mathrm{m}^{3} / \mathrm{s}$ for the studied rivers. However, this method proposes only a minimum base flow as an EWR, and the results are entirely dependent on the study sites. The underlying assumption is that the flow at the inflection point can guarantee a sufficient supply for fish, but this assumption has not yet been proven.

PHABSIM method estimated the mean annual EWR of the studied rivers between 0.12 and $1.63 \mathrm{~m}^{3} / \mathrm{s}$ for the studied rivers. According to the PHABSIM results, different species of the target fishes have different EWRs. Further, 
Table 3 The mean annual values of EWR $\left(\mathrm{m}^{3} / \mathrm{s}\right)$ for the rivers of the Miankaleh wetland watershed

\begin{tabular}{lllllll}
\hline River Name & Nos. & $\begin{array}{l}\text { PHABSIM } \\
\text { model }\end{array}$ & $\begin{array}{l}\text { The wetted } \\
\text { Perimeter } \\
\text { method }\end{array}$ & FDC method & $\begin{array}{l}\text { Aquatic flow } \\
\text { method }\end{array}$ & Tenant Method \\
\hline Gaz & 1 & 0.12 & 1.06 & 0.06 & 0.09 & 0.04 \\
Qarasu & 2 & 1.54 & 1.4 & 0.47 & 0.45 & 0.55 \\
Jafakandeh & 3 & 0.57 & 0.62 & 0.03 & 0.01 & 0.01 \\
Stino & 4 & 1.38 & 1.6 & $*$ & $*$ & $*$ \\
Ab Soma & 5 & 1.63 & 1.86 & $*$ & $*$ & $*$ \\
Karikandeh & 6 & 1.13 & 1.35 & $*$ & $*$ & $*$ \\
Bagho & 7 & 0.17 & 2.03 & 0.14 & 0.1 & 0.06 \\
Nokandeh & 8 & 1.51 & 1.66 & 0.47 & $*$ & 0.01 \\
Polic Rah & 9 & 0.54 & 0.73 & $*$ & $*$ & $*$ \\
Baghokenareh & 10 & 1.23 & 0.91 & $*$ & $*$ & $*$ \\
Vatana & 11 & 0.83 & 0.86 & $*$ & $*$ & $*$ \\
\hline
\end{tabular}

*This method is not applicable for estimating EWR in the study area due to lack of permanent flow or dam the EWR of a target fish will differ during three stages of juvenile fish, adult fish, and spawning. Therefore, the final EWR will cover a range of the optimum river discharges for all of the target fishes and all of their life stages.

Based on the results of the present study, the WettedPerimeter method and habitat simulation methods (PHABSIM) are more reasonable and acceptable methods for this region. The determination of the EWR does not solely save the wetland from its critical situation. What is needed is the discharging of the estimated water into the wetland, which requires the management of water resources and appropriate land use planning.

According to the results, by providing the ecological water requirements of the rivers, the volume of water in the wetland would be about 425 million cubic meters per year (the sum of the EWR for the studied rivers). Rice farms and fish farming pools with high water demands are other drawbacks in allocating the EWR of the Miankaleh wetland. Therefore, appropriate land use planning and modifying rice farms and fish farms should be performed in order to move toward achieving sustainable development goals (Shah et al. 2020). The discharge of rivers into the wetland would not increase the water depth of the wetland since the Miankaleh wetland is like a container that is connected to the Caspian Sea, and the progression of water is primarily due to the Caspian Sea water level change. Providing the EWR of the wetland will be effective in maintaining the salinity of the water, suitable habitat for fish and birds, and the humidity of the coastal soil and thus the survival of fauna and flora in the wetland. Finally, soil moisture and seasonal water flow are other vital components for protecting the Miankaleh wetland from soil erosion and preserving the plant's and animal's habitats (Gholami et al. 2018).

\section{Conclusion}

Unfortunately, the Miankaleh wetland, like many other wetlands in Iran, is at risk of drying for several natural and anthropogenic reasons, including climate changes and uncontrolled exploitation of water resources. Therefore, it is crucial to take necessary measures such as determining and meeting the environmental requirements and water resource management to preserve these vital ecological and hydrological resources.

Considering the arid and semi-arid climate of Iran with multiple seasonal rivers, the use of hydrological methods to determine the environmental flow requirements would not be efficient, and consideration should be given to the hydraulic methods and habitat simulation due to their enhanced performances. Therefore, the hydrologic methods cannot be used for estimating EWR for Iran's wetlands or rivers. Considering the current conditions of the rivers in the Miankaleh wetland drainage basin, it is expected to see a further decrease in the water depth and increase in water salinity, which is a severe threat to fauna and flora in the region. An increase in the wetland water salinity will cause wetland degradation and decreasing biodiversity. Further, an increase in the rivers water salinity will affect irrigated agriculture and adversely impacts on riverine ecosystems. For future studies, it is suggested to use a comprehensive method to determine the EWR of wetlands in Iran. However, the main issue still will be providing the EWR supply for those wetlands.

Acknowledgments We would like to thank the Regional Water Company of Mazandaran for providing the rainfall and hydrometric data.

Funding Not applicable. 


\section{Compliance with ethical standards}

Conflict of interest The authors declare that they have no conflict of interest.

Open Access This article is licensed under a Creative Commons Attribution 4.0 International License, which permits use, sharing, adaptation, distribution and reproduction in any medium or format, as long as you give appropriate credit to the original author(s) and the source, provide a link to the Creative Commons licence, and indicate if changes were made. The images or other third party material in this article are included in the article's Creative Commons licence, unless indicated otherwise in a credit line to the material. If material is not included in the article's Creative Commons licence and your intended use is not permitted by statutory regulation or exceeds the permitted use, you will need to obtain permission directly from the copyright holder. To view a copy of this licence, visit http://creativecommons.org/licenses/by/4.0/.

\section{References}

Adhikari S, Pani KC, Jayasankar P (2019) Water gain and water loss of some freshwater aquaculture ponds at Kausalyaganga, Orissa India. Appl Water Sci 9:121. https://doi.org/10.1007/s1320 1-019-1001-1

Akhtar MP, Roy LB, Vishwakarma KM (2020) Assessment of agricultural potential of a river command using geo-spatial techniques: a case study of Himalayan river project in Northern India. Appl Water Sci 10:81. https://doi.org/10.1007/s13201-020-1165-8

Anthonj C, Githinji S, Kistemann T (2018) The impact of water on health and ill-health in a sub-Saharan African wetland: exploring both sides of the coin. Sci Total Environ 624:1411-1420. https:// doi.org/10.1016/j.scitotenv.2017.12.232

Arthington AH (1998) Comparative evaluation of environmental flow assessment techniques: review of holistic methodologies. Occasional paper no. 26/98. Land and Water Resources Research and Development Corporation, Canberra

Arthington AH, Zalucki JM (2002) Comparative evaluation of environmental flow assessment techniques: review of methods. Land and Water Resources Research and Development Corporation, Canberra

Brinson MM (1993) A hydrogeomorphic classification for Wetlands, Wetlands research program technical report WRP-DE-4, Army Corps of Engineers, Waterways Experiment Station, Vicksburg

Brooks RP (1997) Improving habitat suitability index models. Int Issues Perspect Wildl Manag 25(1):163-167. https://doi. org/10.2307/3783299

Cao F, Lu Y, Dong S, Li X (2020) Evaluation of natural support capacity of water resources using principal component analysis method: a case study of Fuyang district. China Appl Water Sci 10:192. https://doi.org/10.1007/s13201-020-1174-7

Coletti JZ, Vogwill R, Hipsey MR (2017) Water management can reinforce plant competition in salt-affected semi-arid wetlands. J Hydrol 552:121-140. https://doi.org/10.1016/j.jhydr ol.2017.05.002

Cui M, Zhou JX, Huang B (2012) Benefit evaluation of wetlands resource with different modes of protection and utilization in the Dongting Lake region. In: The 18th Biennial conference of international society for ecological modelling. Procedia Environ Sci 13:2-17. https://doi.org/10.1016/j.proenv.2012.01.001

Ghahroudi TM, Sadough SH, Nezammahalleh MA, Nezammahalleh SK (2012) Multi-criteria evaluation to select sites for ecotourism facilities: a case study Miankaleh Peninsula. Anatolia An Int
J Tour Hosp Re 23(3):373-394. https://doi.org/10.1080/13032 917.2012.712872

Gholami V, Booij MJ, Tehrani EN, Hadian MA (2018) Spatial soil erosion estimation using an artificial neural network (ANN) and field plot data. CATENA 163:210-218. https://doi.org/10.1016/j. catena.2017.12.027

Groffman P, Baron J, Blett T, Gold A, Goodman I, Gunderson L, Levinson B, Palmer M, Paerl H, Peterson G, LeRoy PN, Rejeski D, Reynolds J, Turner M, Weathers K, Wiens J (2006) Ecological thresholds: the key to successful environmental management or an important concept with no practical application? Ecosyst 9(1):1-13. https://doi.org/10.1007/s10021-003-0142-z

Homa ES, Vogel RM, Smith MP, Apse CD, Lee A, Sieber J (2005) An optimization approach for balancing human and ecological flow needs. In: Proceedings of the EWRI 2005 world water and environmental resources congress. ASCE, Anchorage, pp 1-12

Jia Z, Luo W (2009) A modified climate diagram displaying net water requirements of wetlands in arid and semi-arid regions. Agric Water Manag 96(9):1339-1343. https://doi.org/10.1016/j. agwat.2009.04.006

Kate S, Kumbhar S, Jamale P (2020) Water quality analysis of UrunIslampur City, Maharashtra. India Appl Water Sci 10:95. https ://doi.org/10.1007/s13201-020-1178-3

King RS, Richardson CJ, Urban DL, Romanowicz EA (2004) Spatial dependency of vegetation-environment linkages in an anthropogenically influenced wetland ecosystem. Ecosystems 7(1):7597. https://doi.org/10.1007/s10021-003-0210-4

Kinhill Engineers Pty Ltd (1988) Techniques for determining environmental water requirements-a review. Technical report series report 40. Department of Water Resources, Victoria

Krasnostein AL, Oldham CE (2004) Predicting wetland water storage. Water Resour Res 40(10):1-12. https://doi. org/10.1029/2003WR002899

Malekmohammadi B, Jahanishakib F (2017) Vulnerability assessment of wetland landscape ecosystem services using driverpressure-state-impact-response (DPSIR) model. Ecol Indic 82:293-303. https://doi.org/10.1016/j.ecolind.2017.06.060

Pattison-Williams JK, Pomeroy JW, Badiou P, Gabor S (2018) Wetlands, food control and ccosystem services in the Smith Creek Drainage Watershed: a case study in Saskatchewan, Canada. Ecol Econ 147:36-47. https://doi.org/10.1016/j.ecole con.2017.12.026

Pusey BJ (1998) Methods addressing the flow requirements of fish. In: Arthington AH, Zalucki JM (eds) Comparative evaluation of environmental flow assessment techniques: review of methods. pp 66-105

Ramsar Handbooks for the wise use of wetlands (2010) Water allocation and management, 4th edition. Ramsar Convention, Handbook 10

Sahour H, Gholami V, Vazifedan M (2020) A comparative analysis of statistical and machine learning techniques for mapping the spatial distribution of groundwater salinity in a coastal aquifer. J Hydrol. https://doi.org/10.1016/j.jhydrol.2020.125321

Sajedipour S, Zarei H, Oryan S (2017) Estimation of environmental water requirements via an ecological approach: a case study of Bakhtegan Lake Iran. Ecol Eng 100:246-255. https://doi. org/10.1016/j.ecoleng.2016.12.023

Sarhadi A, Soltani S (2013) Determination of water requirements of the Gavkhuni wetland, Iran: a hydrological approach. J Arid Environ 98:27-40. https://doi.org/10.1016/j.jaridenv.2013.07.010

Seifi F, Janbaz Ghobadi GR (2017) The role of ecotourism potentials in ecological and environmental sustainable development of Miankaleh Protected Region. Open J Geol 7(4):478-487. https:// doi.org/10.4236/ojg.2017.74033

Shah D, Panchal M, Sanghvi A, Chavda H, Sha M (2020) Holistic review on geosolar hybrid desalination system for sustainable

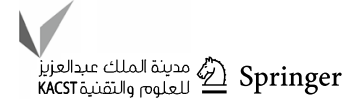


development. Appl Water Sci 10:155. https://doi.org/10.1007/ s13201-020-01241-z

Shaeri Karimi S, Yasi M, Eslamian S (2012) Use of hydrological methods for assessment of environmental flow in a river reach. Int $\mathrm{J}$ Environ Sci Technol 9:549-558. https://doi.org/10.1007/s1376 2-012-0062-6

Tehrani EN, Sahour H, Booij MJ (2018) Trend analysis of hydro-climatic variables in the north of Iran. Theor Appl Climatol 136:8597. https://doi.org/10.1007/s00704-018-2470-0

Tennant DL (1976) Instream flow regimens for fish, wildlife, recreation and related environmental resources. Fish 4(1):6-10. https://doi. org/10.1577/15488446(1976)001\%3c0006:IFRFFW\%3e2.0.CO;2

Tharme RE (2003) A global perspective on environmental flow assessment: emerging trends in the development and application of environmental flow methodologies for rivers. Wiley, Freshwater Research Institute, University of Cape Town, Rhodes Gift

US EPA (2008) Methods for evaluating wetland condition: wetland hydrology. Office of Water, U.S. Environmental Protection Agency, Washington, DC. EPA-822-R-08-024

Xu Y, Wang Y, Li S, Huang G, Dai C (2017) Stochastic optimization model for water allocation on a watershed scale considering wetland's ecological water requirement. Ecol Indic 92:330-341. https://doi.org/10.1016/j.ecolind.2017.02.019

Yang W (2011) A multi objective optimization approach to allocate environmental flows to the artificially restored wetlands of China's yellow river delta. Ecol Model 222:261-267. https://doi. org/10.1016/j.ecolmodel.2010.08.024

Yang Y, Chen H, Yang ZF (2012) Integration of water quantity and quality in environmental flow assessment in wetlands. The 18th Biennial conference of international society for ecological modelling. Procedia Environ Sci 13: 1535-1552. https://doi. org/10.1016/j.proenv.2012.01.146

Ye Z, Li W, Chen Y, Qiu J, Aji D (2017) Investigation of the safety threshold of eco-environmental water demands for the Bosten Lake wetlands, western China. Quat Int 440(Part B):130-136. https://doi.org/10.1016/j.quaint.2016.12.030

Publisher's Note Springer Nature remains neutral with regard to jurisdictional claims in published maps and institutional affiliations. 